\title{
Определение видовой принадлежности представителей рода Liparis (Orchidaceae) на территории «Муравьевского парка устойчивого природопользования» по морфологическим и молекулярным данным
}

\section{Species determination in Liparis (Orchidaceae) based on morphological and molecular data on the territory of "Muravyevsky park of sustainable use of natural resources"}

\author{
Терентьева Е. И, Дегтярева Г. В, Ефимов С. В, Варлыгина Т. И. \\ Terentieva E. I., Degtjareva G. V., Efimov S. V., Varlygina T. I. \\ ${ }^{1}$ Ботанический сад Московского государственного университета им. М. В. Ломоносова, г. Москва, Россия. \\ E-mail:el.terenteva@mail.ru \\ ${ }^{1}$ Botanical Garden, Moscow State University, Moscow, Russia
}

\begin{abstract}
Peфepam. На территории «Муравьевского парка устойчивого природопользования» было проведено обследование популяций видов рода Liparis и первичное определение растений. Так как виды рода Liparis морфологически трудно различимы, то для оценки видовой принадлежности представителей природных популяций были взяты фрагменты растений для молекулярно-филогенетических исследований. В качестве молекулярного маркера были выбраны внутренние транскрибируемые спейсеры (ITS1 и ITS2) участка $18 \mathrm{~S}-26 \mathrm{~S}$ ядерной рибосомной ДНК. На молекулярно-филогенетическом дереве представители из исследуемых популяций разошлись по двум основным кладам. ITS последовательности анализируемых растений каждой клады имеют группоспецифические замены. Анализ морфологических признаков и молекулярных данных позволил нам провести видовую идентификацию представителей природных популяций рода Liparis.
\end{abstract}

Ключевые слова. Амурская область, филогения, ITS, Orchidaceae, Liparis.

Summary. The species of the genus Liparis were sampled on the territory of "Muravyevsky park of sustainable use of natural resources", initial definition of plants was conducted in nature. Morphological characters are insufficient for the species determination of the genus Liparis, so for to assess species identity of representatives of natural populations fragments of plants were taken for molecular phylogenetic studies. The internal transcribed spacers (ITS1 and ITS2) of fragment of 18S-26S nuclear ribosomal DNA were selected as a molecular marker for molecular analyses. The representatives of the research populations of the genus Liparis have separated in the two well-supported clades in the molecular phylogenetic tree. The ITS sequences of analyzed plants of each clade have specific replacement. Analysis of morphological characters and molecular data allowed us to conduct species identification of representatives of natural populations of the genus Liparis.

Key words. Amur region, ITS, Liparis, Orchidaceae, phylogeny.

\section{Введение}

Муравьевский парк - природный парк устойчивого природопользования, расположен на территории Тамбовского района Амурской области России. Он занимает общую площадь 5900 га. По геоботаническому районированию территория Муравьевского парка отнесена к южной степной зоне и представлена лесной, кустарниковой, болотной и луговой растительностью. Флора сосудистых растений парка насчитывает 614 видов (включая 51 реинтродуцированный вид) из 341 рода и 108 семейств (Дарман, 2015).

В результате ботанических исследований, проведенных группой сотрудников биологического факультета МГУ им. М. В. Ломоносова в 2018 г., на лесной территории Муравьевского парка впервые 
были выявлены местонахождения видов из рода Liparis Rich. Ранее представители этого рода в Муравьевском парке не отмечались, а для Амурской области указывались два вида - Liparis makinoana Schlechter и L. japonica (Miq.) Maxim. Найденные нами растения по морфологическим признакам нельзя было отнести ни к одному из этих видов. В природе особи, имеющие зеленые цветки, предположительно были определены нами как L. kumokiri Maekawa, а растения с окрашенными цветками оставались неопределенными.

В настоящее время род Liparis является одним из наиболее сложных в систематическом отношении родов семейства Orchidaceae. Высокая степень внутривидового полиморфизма и относительно малое количество значимых морфологических признаков делает род Liparis предметом дискуссий среди ботаников (Ohwi, 1965; Kim, Kim, 1986; Tsutsumi, Yukawa, 2007; Невский, 1935; Шибнева, 2004, 2007, 2008; Ефимов, 2010; Варлыгина и др., 2017). Согласно литературным данным (Valiejo-Roman et al., 2002; Tsutsumi, Yukawa, 2007; Liang et al., 2012), применение молекулярно-филогенетических методов в дополнение к морфологическим данным помогает решить вопросы, связанные с взаимоотношениями видов внутри сложных таксономических групп.

Цель нашей работы - идентифицировать виды рода Liparis, найденные на территории Муравьевского парка, с использованием морфологических данных и современных молекулярно-филогенетических методов.

На территории России произрастает 6 видов рода Liparis. В европейской части и в Сибири распространен L. loeselii (L.) Rich, на Дальнем Востоке: L. japonica (Miq.) Maxim., L. krameri Franch. et Savat., L. kumokiri F. Maek., L. makinoana Schlechter и L. sachalinensis Nakai (Вахрамеева и др., 2014). Все виды этого рода занесены в Красную книгу Российской Федерации (Камелин, Новиков, 2008).

\section{Материалы и методы}

У растений в наблюдаемых популяциях был исследован диапазон изменчивости морфологических признаков. Проведены измерения высоты растений, длины соцветий и цветоножек, длины и ширины листовой пластинки, отмечены число цветков и степень скрученности губы, так как эти признаки являются диагностическими при определении видов этого рода (Невский, 1935; Шибнева, 2004, 2007, 2008; Ефимов, 2010).

В исследуемых популяциях Liparis были взяты фрагменты вегетативных и генеративных частей растений (23 образца) для молекулярных исследований с целью уточнения их таксономического статуса. В анализ были также включены гербарные образцы, хранящиеся в гербариях (MW, MHA, LE, MAG), и образцы, собранные в ходе экспедиций в 2015-2017 гг. по территории Дальнего Востока (Приморский край и Сахалинская область). В качестве молекулярного маркера были выбраны внутренние транскрибируемые спейсеры (ITS1 и ITS2) участка 18S-26S ядерной рибосомной ДНК. Данный молекулярный маркер постоянно применяется для изучения внутривидовых взаимоотношений в сложных таксономических группах. Выделение ДНК, амплификация и секвенирование участка ITS проводилось согласно методике, описанной в работе Valiejo-Roman et al. (2002).

\section{Результаты и обсуждение}

Для молекулярно-филогенетического анализа были дополнительно привлечены нуклеотидные последовательности (ITS1 и ITS2) трех образцов рода Malaxis (близкородственный таксон к роду Liparis) и 9 видов рода Liparis из базы данных GenBank (https://www.ncbi.nlm.nih.gov/nucleotide/).

Bce ITS последовательности анализируемых видов, выравнивались в программе MUSCLE (Edgar, 2004). Просмотр результатов выравнивания нуклеотидных последовательностей и последующая ручная доработка выполнялась в программе BioEdit version 5.0.9. (Hall, 1999). Набор из 87 выровненных последовательностей (ITS1 и ITS2) содержит 753 позиции, из которых 421 - консервативные, 187 парсимонно-информативные и 145 - парсимонно-неинформативные. По результатам анализа ITS последовательностей были построены молекулярно-филогенетические деревья двумя методами: байесовским методом в программе Mr. Bayes 3.1 (Ronquist, Huelsenbeck, 2003) и методом максимальной экономии в программе PAUP* 4.0b8 (Swofford, 2003). В качестве внешней группы был использован вид Dendrobium crumenatum Sw., выбранный на основании более ранних исследований (Su et al., 2015). По- 


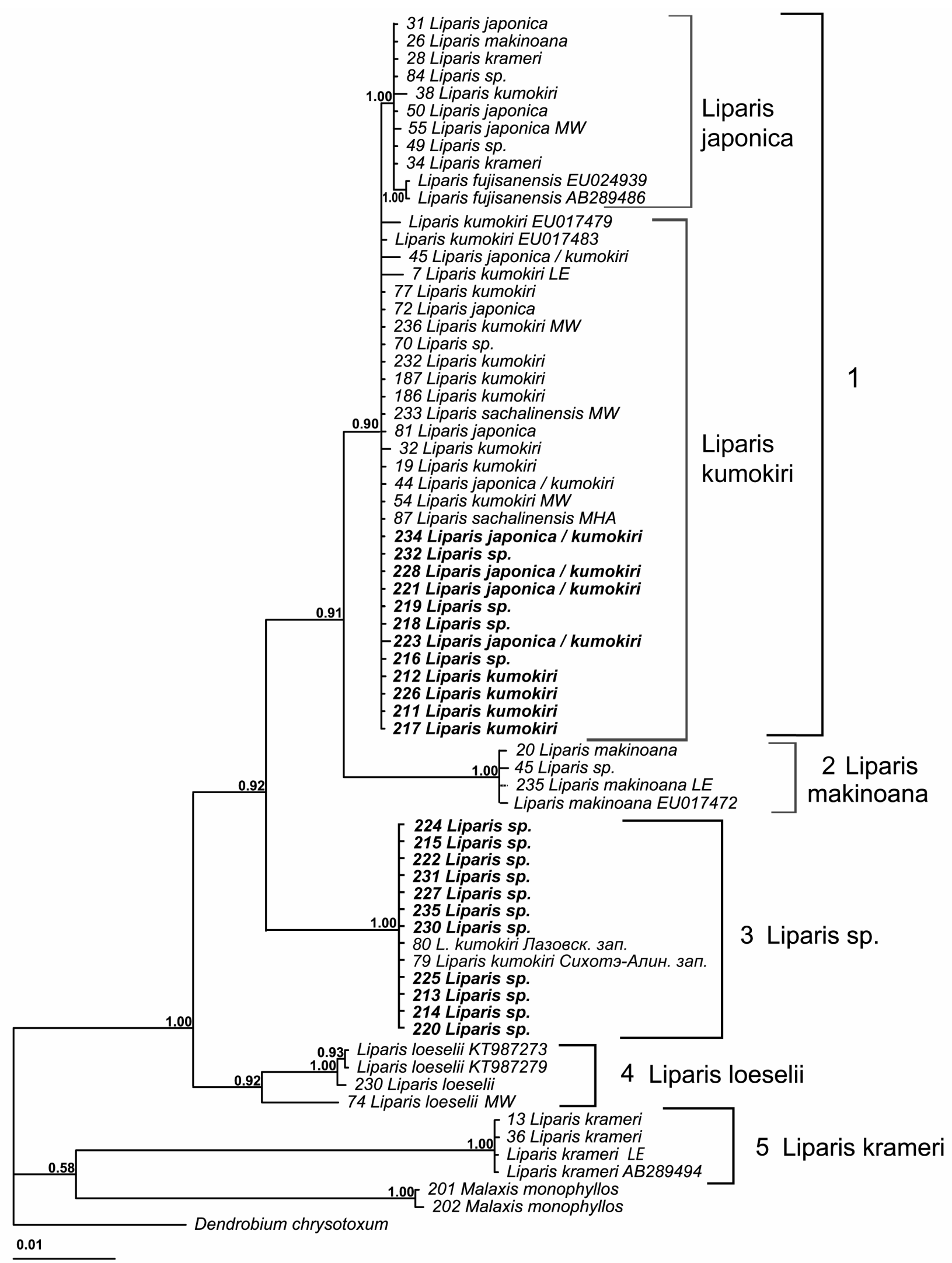

Рис. 1. Молекулярно-филогенетическое дерево, полученное по результатам анализа последовательностей участка ITS ядерной рибосомной ДНК для 69 образцов видов Liparis с помощью байесовского метода в программе Мr. Bayes 3.1 на основании 5500000 деревьев. Числа над ветвями - значения бутстрепа, полученные в результате бутстреп-анализа с помощью метода максимальной экономии. 
лученные топологии деревьев не идентичны, но конгруэнтны в основных узлах. В статье представлено консенсусное молекулярно-филогенетическое дерево, построенное байесовым методом (рис. 1).

Предварительные данные показали, что в целом молекулярные и морфологические данные согласуются между собой. Образцы из популяций разных видов рода Liparis формируют 5 хорошо поддержанных клад, что подтверждает их естественность. На молекулярно-филогенетическом дереве образцы из популяций Муравьевского парка разошлись по двум основным кладам - 1 и 3. Образцы (211, $212,216,217,218,219,221,223,226,228,232,234)$, взятые с растений с зелеными цветками, вошли в кладу (1). Все они имеют идентичные ITS последовательности с реперными образцами L. kumokiri, взятыми из базы данных GenBank и гербариев (LE и MW). В данном случае мы можем предположить, что растения, с которых были взяты образцы, принадлежат к виду L. kumokiri. Это соответствует морфологическим признакам вида (средние показатели у особей в изученных популяциях: высота растений 21,1 см, длина цветоножки - 0, 64 см, длина листа - 10,2 см, ширина листа - 6,9 см, число цветков 14,2 ) и согласуется с литературными данными (Шибнева, 2008; Ефимов, 2010).

Другие образцы $(213,214,220,222,225,235,227,230,231)$ из Муравьевского парка, взятые с растений, имеющих окрашенные цветки, а также растения, собранные в Сихотэ-Алинском и Лазовском заповедниках в 2015 г., сформировали отдельную, высоко поддержанную кладу (3). В Сихотэ-Алинском и Лазовском заповедниках пробы вида р. Liparis были собраны с растений, находившихся в состоянии плодоношения, что затрудняло их идентификацию. Все образцы из клады (3) имеют идентичные ITS последовательности с видоспецифическими заменами, которые маркируют эту кладу. Полученные результаты по анализу ITS последовательностей согласуются с хорошо различимыми морфометрическими данными изученных растений (средние показатели: высота растений - 29,2 см, длина цветоножки $-1,5$ см, длина листа $-11,0$ см, ширина листа $-5,3$ см, число цветков - 20,5). На основании полученных молекулярных и морфологических данных с высокой вероятностью можно предположить, что образцы из популяций рода Liparis в кладе (3) имеют видовой статус.

Таким образом, использование морфологических и молекулярных методов позволило провести таксономическую идентификацию растений рода Liparis в исследованных популяциях. Впервые на лесных участках Муравьевского природного парка в двух местонахождениях были обнаружены популяции двух видов рода Liparis: L. kumokiri и предположительно новый вид, который требует дальнейшего изучения и описания.

Благодарности. Работа выполнена при финансовой поддержке гранта РНФ № 14-50-00029: сбор материала на территории Амурской области, анализ материала морфологическими и молекулярными методами.

\section{ЛИТЕРАТУРА}

Варлыгина Е. И., Дегтярева Г. В., Ефимов С. В., Терентьева Е. И. Популяционные исследования орхидных в заповеднике «Кедровая падь» // Биота и среда заповедников Дальнего Востока, 2017. — Т. 1, № 10. - С. 67-83.

Вахрамеева М. Г., Варлыгина Т. И., Татаренко И. В. // Орхидные России (биология, экология и охрана). М.: Товарищество научных изданий КМК, 2014. — 437 c.

Дарман Г. Ф. Флора территории Муравьевского природного парка // Учёные записки ЗабГУ, 2015. - Т. 60, вып. 1. - C. $11-16$.

Ефимов П. Г. Род Liparis (Orchidaceae) на территории России // Бот. журн., 2010. — Т. 95, № 10. — С. 14581480.

Камелин Р. В., Новиков В. С. Растения и грибы // Красная книга Российской Федерации.- М.: Товарищество научных изданий КМК, 2008. - Т. 1. - 855 с.

Невский С. A. Род Liparis L. C. Rich. // Флора СССР. - Л.: Изд-во АНСССР, 1935. - Т. 4. - С. 601-604.

Шибнева И. В. Liparis kumokiri (Orchidaceae) на Дальнем Востоке России // Бот. журн., 2004. — Т. 89, № 10. - С. $1633-1636$.

Шибнева И. В. Виды рода Liparis (Orchidaceae) на юге материковой части Дальнего Востока России // Фундаментальные и прикладные проблемы ботаники в начале XXI века, Петрозаводск, 22-27 сент. 2008 г.: материалы Всерос. конф. Петрозаводск: Карельский научный центр, 2008. Ч. 3. С. 148-150. 
Шибнева И. В. Заметки о видах рода Liparis (Orchidaceae) из Приморского края // Растения в муссонном климате, Владивосток, 10-13 окт. 2006 г.: материалы Всерос. конф. Владивосток, 2007. - С. 264-268.

Edgar, $\boldsymbol{R}$. C. MUSCLE: multiple sequence alignment with high accuracy and high throughput // Nucleic Acids Research, 2004. - Vol.32. - P. 1792-1797.

Hall, T. A. BioEdit: a user-friendly biological sequence alignment editor and analysis program for Windows 95/98/ NT. Nucl. Acids Symp., 1999. - Ser. 41. - P. 95-98.

Kim S. N., Kim Y. S. Morphological and cytological Study on genus Liparis in Korea // Kor. J. Plant Tax., 1986. - Vol. 16. - P. 59-88.

Liang Z., Wei W., Yi R., Julien B. B. Floral Development in Asteropyrum (Ranunculaceae): Implications for ITS Systematic Position// Annales Botanici Fennici, 2012. Vol. 49, No.1-2. P. 31-42.

Ohwi J. Flora of Japan. - Washington, 1965. - 1067 p.

Ronquist F. R., Huelsenbeck J. P. MrBAYES 3: Bayesian phylogenetic inference under mixed models // Bioinformatics, 2003. No 19. P. 1572-1574.

Su Y. Y., Huang Y. L., Chen L. J., Zhang P. W., Liu Z. J., Zhang G. Q. Liparis wenshanensis, a new orchid species from China; Evidence from morphological and molecular analyses // Phytotaxa, 2015. Vol. 204, No. 4. P. $253-264$.

Swofford D. L. PAUP*: version 4.0. Sunderland, Massachusetts: Inc. Publishers, Sinauer Associates, 2003.

Tsutsumi C., Yukawa T., Lee N. S et al. Phylogeny and comparative seed morphology of epiphytic and terrestrial species of Liparis (Orchidaceae) in Japan. // Plant Res., 2007. - Vol.120. - P.405-412.

Valiejo-Roman C. M., Terentieva E. I., Samigullin T. H., Pimenov M. G. Relationships among genera in Saniculoideae (Umbelliferae) and connected taxa inferred from ITS sequences of nuclear ribosomal DNA// Taxon, 2002. - Vol. 51. - P. 91-101. 